\title{
The scientific correspondence of Arcangelo Scacchi
}

\author{
Rossella De Ceglie \\ Seminario di Storia della Scienza, Università degli studi di Bari, Italy
}

\begin{abstract}
The scientist Arcangelo Scacchi (1810-1893), is today rarely mentioned in histories of Italian science in the nineteenth century. Even a brief consideration of his career, however, reveals that his work was of great importance to the scientific community of his age. For more than fifty years he was Professor of Mineralogy at the University of Naples and Curator of the Royal Mineralogical Museum, which under his guidance enjoyed a period of unprecedented success. The as yet unpublished Scacchi papers shed interesting light on the world of this Italian naturalist. His correspondence reveals much about Scacchi's role in the scientific community both in Italy and abroad, and illustrate the extent to which he was involved in contemporary debates and research in the fields of geology, mineralogy, volcanology and crystallography.
\end{abstract}

Key words geology-mineralogy - volcanology correspondence - uniformitarianism

Vienne, le 7.3.90

«Mon cher Maître! Acceptez, je vous prie, mes renseignements sincères pour le nouvel envoi de mémoires que je viens de recevoir et qui m'apprend, que votre activité est encore tout à fait celle de la jeunesse, dirigée toutefois par l'expérience et la sagacité que nous admirons tout à vous, mon cher maître». E. Suess (fig. 1).

It was with these words that, in March 1890, the famous Austrian geologist Edward Suess $\left({ }^{1}\right)$ addressed Arcangelo Scacchi (1810-1893), who was then in his eighties and had been teaching Mineralogy at the University of Naples for over fifty years, during which time he had also been Dean $\left(^{2}\right)$. Amongst his other roles, he was also the Curator of the Royal Min-

Mailing address: Dr. Rossella De Ceglie, Seminario di Storia della Scienza, Università degli Studi di Bari, Palazzo Ateneo, P.zza Umberto I, Bari, Italy; e-mail: deceglie@filosofia.uniba.it eralogical Museum, which, under his guidance enjoyed a period of unparalleled success. Scacchi, the «brilliant crystallographer», was «the first Italian mineralogist to win international recognition for his work», $\left({ }^{3}\right)$ and to achieve the honour of having a mineral - scacchite - named after him. Scacchi began by studying Vesuvius and the geology of the Campania region but, from the beginning of the 1830s, broadened his research into the fields of palaeontology, geology, chemistry and mineralogy.

Although today his name is seldom mentioned in histories of Italian science in the nineteenth century $\left({ }^{4}\right)$, even a brief look at his life and career illustrates how eminent a figure he was in the scientific community of his day. Scacchi's vast correspondence reveals how he occupied a position right at the centre of a network of contacts made up of some of the most important Italian and international scientists of the age.

The South of Italy was full of places of interest - Naples and Vesuvius, Sicily and Etna for naturalists, who flocked there on field trips. Scacchi was a point of reference for the visiting scientists and he frequently accompanied them on their expeditions. An extraordinary rapport seems to have developed between northern sci- 


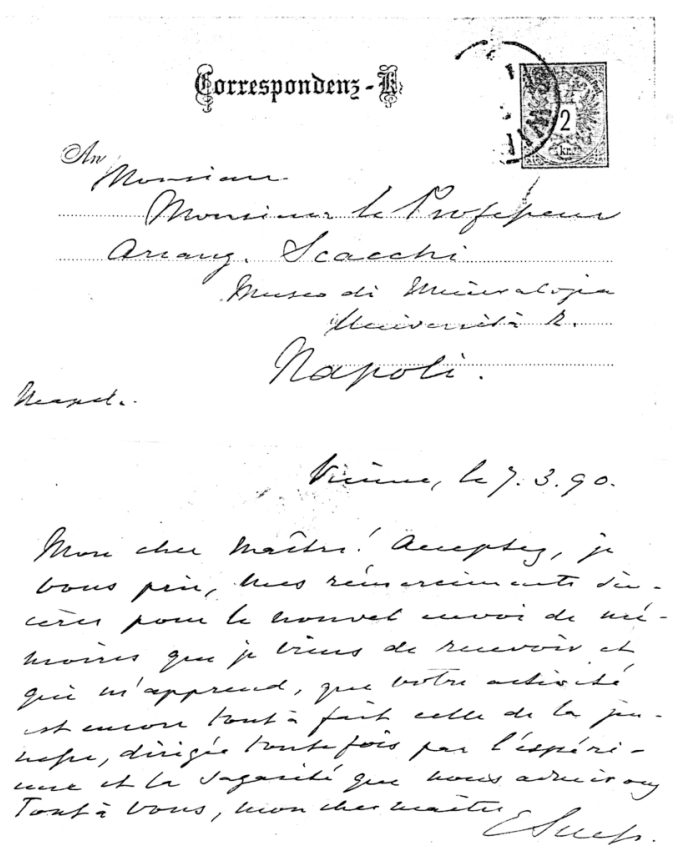

Fig. 1. Letters from Edward Suess to Scacchi, Vienna, 7 March 1890, Biblioteca Fondazione Pomarici Santomasi, Gravina in Puglia (Bari, Italia), Cart. Scacchi, B4, F 11, N 131.

entists, who came down to Naples and the surrounding countryside on geological and volcanological field trips, and leading local scholars: besides Scacchi, other noteworthy academics included Oronzio Gabriele Costa and the Gemmellaro brothers $\left(^{5}\right)$. The area became a kind of «promised land» where geologists from all over Europe could meet established colleagues.

Scacchi's letters, most of which are in the keeping of the Pomarici Santomasi Foundation in Gravina in Puglia, his birth place $\left(^{6}\right)$, provide important clues on the environment in which the naturalist grew up and worked. They also illustrate the key role Scacchi played in the scientific community both in Italy and abroad in the nineteenth century, and in research in the fields of geology, mineralogy, volcanology and crystallography.

The many letters written to Scacchi by vari- ous Italian and foreign scholars cover a long period of time, from approximately 1830 until the death of the naturalist in 1893; they reveal how Scacchi was at the centre of an international network of scholars and underline how highly he was regarded by the leading academics of the day, who saw him as a valuable point of reference for their own research. The letters also reflect the diversity of Scacchi's interests which ranged freely across disciplines as varied as zoology, palaeontology, chemistry, geology, volcanology, mineralogy and crystallography.

The letters dating from the 1830s confirm that initially Scacchi's main focus was on zoology, which would subsequently become of secondary interest to him, as he devoted an increasing amount of time and energy to geology and mineralogy. It is also evident from the correspondence in this early period of his career that he was already well-known both in Italy and abroad $\left({ }^{7}\right)$. Foreign scholars at leading research centres were interested in Scacchi's work and followed his career closely, asking him for materials and specimens as well as for his scientific opinions $\left({ }^{8}\right)$. A case in point is that of the French ichthyologist Valenciennes $\left({ }^{9}\right)$ from the Muséum d'Histoire Naturelle in Paris, who was interested in Scacchi's malacological studies and in the clavagella specimens sent to Scacchi by Brongniart $\left({ }^{10}\right)$. In Belgium too, Scacchi's work on shells was well-known and his fame as a mineralogist was beginning to spread; as early as 1839, Andrè Hubert Dumont $\left({ }^{11}\right)$, a geologist at Lieges University, expressed interest in exchanging mineral specimens with his Italian colleague $\left({ }^{12}\right)$.

Scacchi's fame - as well as his collections grew over the following ten years as he expanded his research. Again, his correspondence shows the extent of his involvement with some of the most important national and international scholars of the day, and with prestigious research centres.

Scacchi's correspondence with his fellow Italian, Filippo Corridi $\left({ }^{13}\right)$, offers evidence of the size and quality of the collection he assembled $\left({ }^{14}\right)$, as do letters written by the geologist Giovanni Capellini $\left({ }^{15}\right)$ : Capellini provided the geological museum in Bologna with mineral samples from Vesuvius that he had been given by Scac- 
chi, whose work in the scientific field he considered to be without equal $\left({ }^{16}\right)$. Exchanges of books and minerals also took place between Scacchi and Angelo Sismonda $\left({ }^{17}\right)$, the Director of the Mineralogical and Geological museum in Turin.

Scacchi enjoyed contact with numerous scientists from abroad. In September 1847, the chemist Friedrich Wöhler $\left({ }^{18}\right)$ visited Naples and, along with Scacchi and Piria $\left({ }^{19}\right)$, went on an excursion to Vesuvius, while in the autumn of 1850 Scacchi accompanied three scientists from Berlin, Eilhard Mitscherlich $\left({ }^{20}\right)$, Gustav Rose $\left.{ }^{(21}\right)$ and Justus Roth $\left({ }^{22}\right)$, to Solfatara, Monte Nuovo and Vesuvius. After the visit Scacchi wrote to Mitscherlich, thanking him for «extremely pleasant and instructive conversations» $\left.{ }^{23}\right)$, a sentiment no doubt shared by the German scholars too, as Rose and Mitscherlich both recalled their stay in Naples with their friend Scacchi «with the greatest pleasure» $\left({ }^{24}\right)$. The high esteem they held him in led to an enduring friendship, and to their receiving mineral samples and papers from him. According to Rose, Scacchi's work on humite $\left({ }^{25}\right)$ was remarkable $\left({ }^{26}\right)$. Rose himself checked Roth's German translation of Scacchi's work and proof-read the final text and illustrations, which were published in Poggendorff's Annalen der Physik in $1853\left({ }^{27}\right)$.

Scacchi was in contact with various German scientists, such as the mineralologist Paul Groth $\left({ }^{28}\right)$, who included Scacchi's name in the list of contributors to his journal of crystallography and mineralogy ( $\ll$ Zeitschrift fur Krystallographie und Mineralogie»), which had been founded in $1877\left({ }^{29}\right)$.

Scacchi's work was well-known outside the Kingdom of Naples thanks to correspondence between scientists: his scientific publications were read and circulated abroad and some publications were translated and published in specialist journals $\left({ }^{30}\right)$. Scacchi's contacts were not limited to Europe: from 1853 to 1890 he corresponded with the American geologist and zoologist James Dwight Dana $\left.{ }^{31}\right)$.

Scacchi himself closely followed the work published by other scholars; he often received papers written by academics who had consulted him in the course of their research, as in the case of Wilhelm Körner $\left(^{32}\right)$.

Many of those who corresponded with
Scacchi actually visited him personally in Naples whilst in Italy on research trips. On these occasions Scacchi - often together with his colleague Luigi Palmieri $\left({ }^{33}\right)$ and his student Guglielmo Guiscardi $\left(^{34}\right)$ - usually accompanied the scientists on their expeditions around the region. One such visitor was the Scottish geologist, Charles Lyell $\left({ }^{35}\right)$ who, after a first, crucial trip to Italy in 1828 , returned in 1858 and visited Monte Nuovo, Vesuvius and Pompei with Scacchi. The correspondence reveals how the two scientists worked together.

It is well-known that Lyell is regarded as an important figure in the history of geological studies on account of his revolutionary views ${ }^{(36}$ ) about how events from the past can be explained in terms of phenomena present today, and his rejection of theories of unknown or cataclysmic causes. Lyell's work would in fact help to demolish catastrophe theories. He introduced into geology the concepts of unlimited time and natural forces, and the theory that the physical and geological phenomena at work today function with the same intensity as in the past. The Earth's past could be explained by making reference to present phenomena, such as the movement of the earth's crust due to volcanic activity, earthquakes or erosion due to wind or rain. The development of Lyell's new point of view was significantly affected by his direct study of the Tertiary and volcanoes while on his visit to Italy in $1828\left({ }^{37}\right)$. Through direct observation of volcanoes, Lyell intended to elaborate on Scrope's theory $\left({ }^{38}\right)$ that volcanoes were formed as a consequence of the accumulation of lava and detritus around eruptive channels and could not therefore be explained by von Buch's theory of craters $\left({ }^{39}\right)$. For Lyell, not only volcanoes but all geological phenomena could be explained in terms of processes still functioning today. In this context, Lyell's study of the Tertiary was of particular importance: the observation of significant changes in the most recent strata (the Tertiary) was fundamental to his project. His observations were made while he was in Italy, first in Naples, visiting Vesuvius, Monte Nuovo and the Temple of Serapis, and afterwards on Ischia, where he was struck by his discovery at an altitude of $600 \mathrm{~m}$ of shell fossils of extant species. 
There is no specific evidence of any meeting between Lyell and Scacchi during the former's first visit in 1828, although it is known that Scacchi was already in Naples by that date. What is certain, however, is that over the following years the two wrote to each other regularly and certainly met during Lyell's second visit to Naples in 1857.

The two scientists enjoyed a friendship based on cooperation and mutual respect. Before his 1857 visit, Lyell wrote to Scacchi thanking him for sending him his precious work on the geology of terrestrial volcanoes in the Naples area and expressing keen interest in reading other work by the naturalist:

«Monsieur, Vous avez eu la bonté de m'envoyer vos mémories très precieux sur la géologie des terreau volcaniques des environs de Naples, que j'ai cité dans mon mémoire publié dans le Journal de la Soc. Geol.que de Londres [...] Avez-vous continué vos publications comme vous avez promis? Je suis très curieus de les voir [...]» (fig. 2).

In the «memoires trés precieux», mentioned here by Lyell and referred to in The Quarterly Journal of The Geological Society in $1849\left({ }^{40}\right)$, Scacchi dealt with the subject of the volcanic regions of Campania $\left({ }^{41}\right)$ and rejected the theory of crater upheaval for Astroni, Monte Nuovo and other neighbouring cones. Lyell agreed completely with Scacchi: Monte Nuovo could only have been formed by an eruption. Scacchi had also mentioned that the ancient temple to Apollo or Serapis (near Pozzuoli), the walls of which are perfectly perpendicular, could not have remained so if the Monte Nuovo cone had been formed through a process of upheaval.

«Since writing the above I have received a memoir on the volcanic region of Campania by Signor Arcangelo Scacchi, published in the Memoirs of the Royal Academy of Naples for 1849, in which he entirely concurs with me in rejecting the theory of upheaval for Astroni, Monte Nuovo, and other cones of that district.» $\left({ }^{42}\right)$.

Scacchi's observations about Monte Nuovo and the Temple of Serapis, which underlined the unsustainability of a theory of crater upheaval, were taken up by Lyell in his Principles of Geology (fig. 3) $\left(^{43}\right)$. Scacchi's opposition to

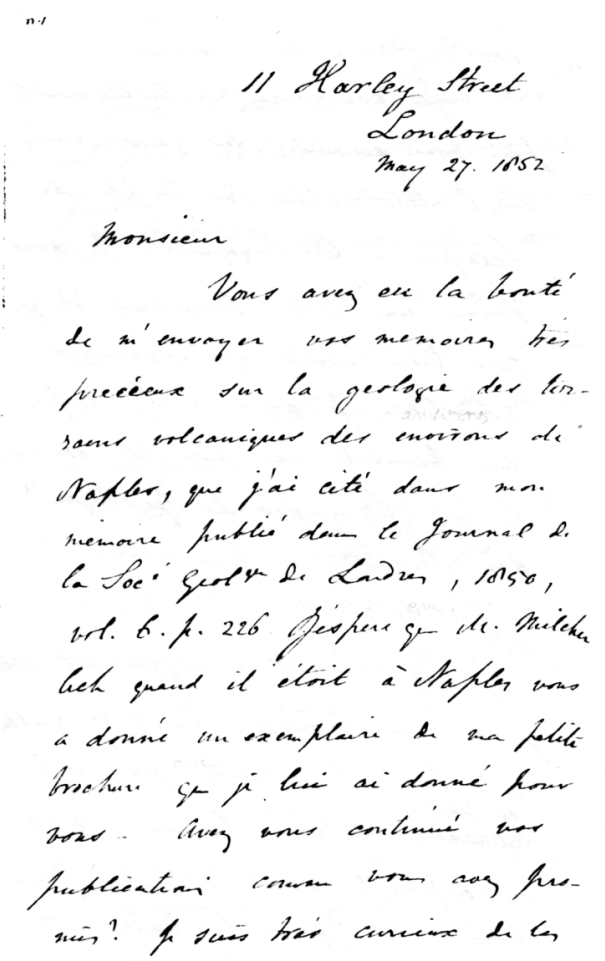

Fig. 2. Letters from Charles Lyell to Scacchi, London, 27 May 1852 (Biblioteca Fondazione Pomarici Santomasi, Gravina in Puglia (Bari, Italy), Cart. Scacchi, B 4, F 11, N 30.

this theory is mentioned in his letter to Monsignor Lavinio de Medici Spada $\left(^{44}\right)$ in which, on the subject of the geologist Giacinto Provana di Collegno $\left({ }^{45}\right)$, he says that, while respecting and liking the man as a friend, he was however forced to take scholarly distance from him owing to his becoming an Italian apologist for the theory of crater upheaval.

In a letter of 1852, Lyell asked Scacchi for copies of his most recent publications, not only because of his general interest in his colleague's work, but, more specifically, because he desired information regarding the current condition of the Temple of Serapis, as he was due to give a lesson on it. He was also preparing a new edition of Principles in which ample space was to be devoted to the subject $\left({ }^{46}\right)$. 


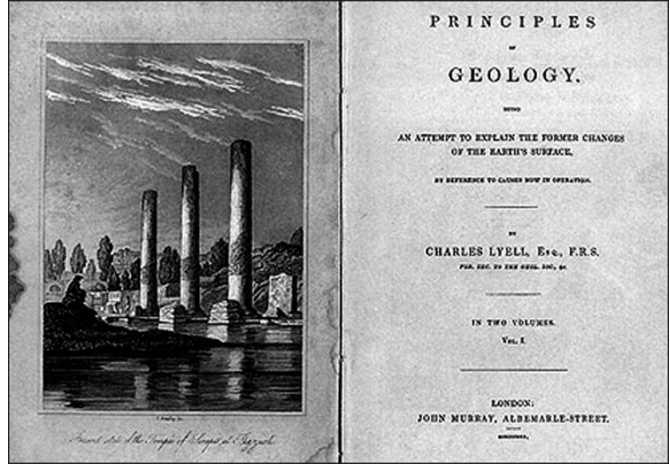

Fig. 3. Temple of Serapis, Pozzuoli (Neaples), on the cover of Lyell's Principles of Geology, 1830-33.

Lyell considered the Temple of Serapis highly important, and in fact an illustration of it appeared on the cover of Principles of Geology as a kind of emblematic representation of his theory that past events could be attributed to ongoing phenomena and not to any catastrophe theory. The columns of the Temple bore evidence of a series of upheavals: marine mollusc imprints indicated that the edifice - built during the Roman period on dry land - had later sunk into the sea; subsequently, the Temple ruins were thrust upwards to their present position above sea level. The Temple suggested to Lyell how a succession of small changes could, over a given length of time, have tremendous effects, such as the creation of mountain chains or the sinking of continents. Lyell's theory integrated human history with geological history, the past with the present, and used a man-made monument (the Temple) as a witness to geological change $\left({ }^{47}\right)$. The Temple of Serapis, like Monte Nuovo (formed in 1538), provided tangible evidence of the effects of geological processes through history $\left({ }^{48}\right)$.

A significant paragraph in Lyell's Principles is devoted to the Temple $\left({ }^{49}\right)$; it describes the changes in the land and sea levels in the area around Pozzuoli from the beginning of the Christian era, which consisted of downwardsinking and upward-thrusting movements in the Bay of Bays, to the north and south of Pozzuoli, including Monte Nuovo and Solfatara $\left({ }^{50}\right)$. In response to Lyell's request $\left({ }^{51}\right)$, Scacchi examined the Temple and deduced that for several years there had been practically no further sinking. Lyell himself had made a careful examination of the Temple and noted that at high tide almost two feet of water entered it.

A letter dated March $1855\left({ }^{52}\right)$ from Lyell to Leonard Horner $\left({ }^{53}\right)$ mentions Scacchi's opinions and work. Lyell notes $\left({ }^{54}\right)$ how Scacchi's extremely interesting observations on the 1850 eruption of Vesuvius and on all that had occurred from 1845 to 1850 - observations which had been passed on to him by Eilhard Mitscherlich $\left({ }^{55}\right)$, who was also in contact with Scacchi completely undermined the theories proposed by von Buch and Dufresnoy $\left({ }^{56}\right)$. In expressing surprise at the influence von Buch's theories had enjoyed, the Scottish geologist wrote:

«In one paper Scacchi is so astonished at Dufresnoy's assertions, who never walked once over one whole side of Somma, that he says in so many words, 'that if the French savant was ever at Naples, he could never have gone out of his house, or only night'» $\left({ }^{57}\right)$.

During his stay in Naples in the autumn of 1857, Lyell wrote to George Hartung $\left({ }^{58}\right)$ to update him on the latest interesting observations made in the area. He was particularly interested in the movement and varying speed of the lava flows, which led him to elaborate new theories. Lyell noticed that all the lava flows described by Scacchi between 1850 and 1855 , had been covered up by new, steeper flows. He examined them and the walls of Monte Somma, once again agreeing with Scacchi:

«I begin seriously to doubt whether any of the rents, which are now dikes, imply distension as De Beaumont assumes. Scacchi's observations seem to show that they are rather the effect of a failure of support, and attended with a partial sinking. But I will explain more when I have devoted more days to the examination of this region» $\left({ }^{59}\right)$.

Scacchi made sure that his young student-assistant Guiscardi was available to accompany Lyell on his various expeditions around the area. Lyell mentions his «good fortune» in having such a companion $-\ll$ no one possesses a more 
thorough knowledge of the structure and composition of both Vesuvius and Monte Somma» $\left({ }^{60}\right)$. Several months later, when the Irish engineer Robert Mallet $\left({ }^{61}\right)$ visited the Kingdom of Naples to examine the effects the earthquake had had on the provinces $\left({ }^{62}\right)$, he brought with him a letter from Lyell to Scacchi, in which the Scotsman asked Scacchi to give Mallet advice, which would be «de la plus haute importance» $\left({ }^{63}\right)$.
Scacchi was always there, always ready to work together with his Italian and foreign colleagues, and to show them around the land that he knew so well and would continue to study until almost the end of the century. In 1891, during the celebrations organized for his fifty years of teaching, he was described quite simply as having «contributed so much to the progress of geology and mineralogy.» $\left({ }^{64}\right)$.

\section{Notes}

$\left({ }^{1}\right)$ Edward Suess (1831-1914), the Austrian geologist and palaeontologist, was Professor of Geology at Vienna from 1857. After working initially in the field of palaeontology, he subsequently devoted himself to plate tectonics and the study of strata. His masterpiece, Das Antlitz der Erde, (Wien, Preg, Tempsky; Leipzig, Freytag, 1885-1909), was a history of geological studies. In his studies of the Alps, he focused primarily on orogeny. He was the first to introduce the concept of Gondwana.

$\left(^{2}\right)$ In 1844 Scacchi held the Chair of Mineralogy at the University of Naples, and was curator of the Real Museo Mineralogico. In 1865 he was elected Dean; he was re-elected in 1875.

$\left({ }^{3}\right)$ Millosevich, F. (1936), p. 991. Translations mine.

$\left({ }^{4}\right)$ Apart from obituary notices and anniversary or commemoration tributes, which date to the end of the 19th and beginning of the 20th century. More recently, A. Mottana has studied Scacchi and his work in various fields (e.g. MotTana, A., 1993; 2001).

$\left({ }^{5}\right)$ Oronzio Gabriele Costa (1787-1867), a zoologist and palaeontologist from Naples, offered Charles Lyell precious help in the identification of shell fossils in the Kingdom of Naples. Of the Gemmellaro brothers, who were working in Sicily, Carlo (1787-1866), a naturalist and volcanologist, was the one who travelled the most and was most influenced by English culture; Giuseppe (1788-1876), a volcanologist, often accompanied the geologist Charles Lyell on his excursions to Etna; Mario (1773-1839), built the first refuge on Etna, which was later enlarged with funding from England (it was this refuge that Lyell described as the English House).

$\left({ }^{6}\right)$ The Scacchi archive, in the Biblioteca della Fondazione Pomarici Santomasi, Gravina in Puglia (in the Province of Bari), consists of numerous letters sent to Scacchi (some 200 correspondents have been listed so far, but a more precise figure is expected to emerge in the future). The collection also includes private papers regarding his work and qualifications, awards, budget, household affairs, diaries, notes and sonnets, funeral notices and telegrams.

There are also a series of letters housed in other libraries in Italy and abroad, including: Accademia delle Scienze, Turin, Italy; Biblioteca dell' Archiginnasio, Bologna, Italy; Biblioteca Comunale Saffi, Forlì, Italy; Biblioteca Comunale, Palermo, Italy; Biblioteca Nazionale Centrale, Florence, Italy; Bayerische Staatsbibliothek, Monaco, Germany; Biblioteca Universitaria, Pisa, Italy; Deutsches Museum, Monaco, Germany; Museo Civico di Storia Naturale, Milan, Italy; Staatsbibliothek, Berlin, Germany.

( ${ }^{7}$ See, for example, the letter from Carlo Passerini to Scacchi, Florence, 31 March 1838, Biblioteca Fondazione Pomarici Santomasi, Gravina (hereafter: BPSG), Cart. Scacchi, B4, F 12, N 75.

$\left({ }^{8}\right)$ Scacchi kept a shell collection made up of «local and exotic» specimens which, in 1837, was bought by the Zoological Museum at the University of Naples (Mss Neapolitan State Archives, Min. Pubbl. Istr., Fasc. 284, II): the sale of this collection marked a significant change in the direction of Scacchi's research: from a general interest in zoology and palaeontology he switched to more specific geological pursuits. After graduating in 1832, Scacchi tried (without success) to win the Chair of Zoology left vacant after the death of Luigi Petagna. Then, in 1836, when the Bourbon government awarded the Chair to Oronzio Gabriele Costa, Scacchi decided to devote himself to mineralogy.

$\left({ }^{9}\right)$ The naturalist Achille Valenciennes (1794-1865) was considered the leading French ichthyologist of the nineteenth century. A disciple of Cuvier, he worked with the latter on Histoire naturelle des poisson (1828-1849), a project he continued after the death of Cuvier. In 1832 he took over the Chair of Invertebrate Zoology at the Muséum d'Histoire Naturelle in Paris.

$\left({ }^{10}\right)$ Alexandre Brongniart (1770-1847), a geologist and palaeontologist renowned for his ability to identify the age of fossils in rock strata, was the first to study the trilobite. He worked with Cuvier and conducted research 
in the north of Italy, comparing the organic remains in the Tertiary formations around Vicenza with those in the area around Paris.

$\left({ }^{11}\right)$ Andrè Hubert Dumont (1809-1875), the Belgian geologist and Professor of Geology at the University of Lieges, was primarily interested in the geology and palaeontology of Belgium. He organised geological surveys of the country and was also responsible for the drawing up of a geological map of Belgium. In addition, he wrote numerous interesting papers on the mineral resources of his native country. Dumonite, a yellow-ochre rhombic mineral, basic phosphate uranium hydroxide and lead, is named after him.

$\left({ }^{12}\right)$ Letter from Edmond De Selys Longchamps to Scacchi, Lieges, 12 January 1839, BPSG, Cart. Scacchi, B 4, F 11, N 6.

$\left({ }^{13}\right)$ Filippo Corridi (1806-1877), a mathematician from Livorno, taught differential calculus at the University of Pisa. From 1850 he was the Principal of the Scuole Tecniche delle Arti e Manifatture. He wrote La geometria: libri dieci, Florence, Piatti, 1843.

$\left({ }^{14}\right)$ Letter from Scacchi to Corridi, Naples, 13 December 1852; 23 August 1853, Biblioteca Universitaria, Pisa, Ms 922, fasc. 175.

$\left({ }^{15}\right)$ The geologist Giovanni Capellini (1833-1922) studied at Pisa. After a period spent in Paris, he became a teacher of natural history in Genoa and in 1861 obtained a professorship in Bologna. He was the Curator of the geological museum in Bologna. He organized conferences, founded the Società Geologica Italiana and travelled extensively in America and Europe.

$\left({ }^{16}\right)$ Letter from Capellini to Scacchi, Bologna, 28 July 1889, BPSG. Letter from Capellini to Scacchi (18731890), BPSG, Cart. Scacchi, B4, F11, N 95; Letter from Scacchi to Capellini (1873-1890), Biblioteca dell'Archiginnasio, Bologna, Fondo Capellini, CXXX.

$\left({ }^{17}\right)$ Angelo Sismonda (1807-1878), a geologist and palaeontologist from Conegliano d'Alba. From 1832 he was Professor of Mineralogy at the University of Turin and curator of the mineralogical and geological museum. Particularly interested in the Alps, his best-known works include: Notizie e schiarimenti sulla costituzione delle Alpi Piemontesi, Turin, Stamp. Reale, 1845. See letters from Sismonda to Scacchi (1844-1875), BPSG, B 4, F 11 , N 14. $\left({ }^{18}\right)$ Letter from Wolfang Sartorius von Waltershausen to Scacchi, Gothenberg, 27 August 1847; BPSG, B 4, F 11, N 22. Friedrich Wöhler (1800-1882), a German chemist, developed the first organic synthesis (urea). Invited by Berzelius to work in his laboratory in Stockholm, he later returned to Germany. In 1832 he visited Cassel with Liebig; in London he met Faraday; in 1836 he won the Chair in Gothenberg. He worked with Liebig and Poggendorff on the first six volumes of the dictionary of pure and applied chemistry.

$\left({ }^{19}\right)$ Raffaele Piria (1814-1865) was one of the leading Italian chemists of the nineteenth century. He studied in Paris, where he met Macedonio Melloni, with whom he became friends. In 1839 he returned to Naples, where he taught a private course in chemistry. In 1842 he won the Chair in Chemistry at Pisa and in 1857 moved to the University of Turin. He studied salicin. Stanislao Cannizzaro was a student of his. Piria wrote Trattato elementare di chimica inorganica, Florence, Le Monnier, 1851.

$\left({ }^{20}\right)$ Eilhard Mitscherlich (1794-1863), a chemist and mineralogist from Berlin, studied crystallography, first with Link and later with Berzelius in Stockholm. In his later career he focused on geology and, in particular, volcanic regions. He was a brilliant writer of scientific manuals. His research included work on the relation between crystal shapes and their chemical composition (he discovered isomorphism). Mitscherlichite, a blue-coloured, tetragonal mineral discovered inside Vesuvius and composed of copper chloride and potassium hydrate - the product of a process of sublimation - was named after him.

$\left({ }^{21}\right)$ Gustav Rose (1798-1873), mineralogist, Professor of Mineralogy at the University of Berlin (from 1826) and Curator of the local mineralogical museum (from 1856). He studied the relation between the shape and chemical composition of minerals and between crystal shapes and their electrical properties. In 1829 , together with von Humboldt, he embarked on a long journey to the Urals and central Asia where, notably in Russia, he collected an impressive amount of mineralogical material.

${ }^{(22}$ Justus Ludwig Adolph Roth (1818-1892), a geologist and petrographer, was Professor of Petrography and Geology at the University of Berlin (from 1867). He was one of the first scientists to apply chemico-microscopic methods, which had only recently been introduced into petrological studies, to the study of the rocks of Vesuvius, Monte Somma and the island of Ponza. He contributed to the geological map surveys of Lower Silesia.

$\left({ }^{23}\right)$ Letter from Scacchi to Mitscherlich, Naples, November 1850, Deutsches Museum Munich, HS 00884. Translation mine.

$\left({ }^{24}\right)$ Letter from Rose to Scacchi, Berlin, 12 August 1851, BPSG, B 4, F 11, N 23. Translation mine.

$\left({ }^{25}\right)$ SCACCHI, A., (1851).

$\left({ }^{26}\right)$ Letter from Rose to Scacchi, Berlin, 12 August 1851, BPSG; see also letter from Rose to Scacchi, Berlin, 14 August 1852, BPSG («cependant l'Humite est devenue une substance si intéressante par vos recherches remarquables, que je voudrai bien en avoir d'autres»). 
$\left({ }^{27}\right)$ Erganzungsband III, Leipzing, 1853, pp. 161-167.

$\left({ }^{28}\right)$ Letter from Scacchi to Paul Groth, 1876-1883, Bayerische Staatsbibliothek, Munich, Grothiana X Scacchi. Paul Groth (1843-1927), mineralogist and crystallographer, taught first in Berlin (1870) and then from 1872 in Strasburg, where he established a mineralogical collection with a catalogue (ed. 1878) which was considered a model for the whole period. In 1883 he was awarded the chair of mineralogy in Munich and the curatorship of the Bavarian State collection, to which he added samples from mineral deposits in the Alps. His scientific research was conducted principally in the fields of structural and microscopic crystallography and crystal chemistry. The mineral grothite was named after him.

$\left({ }^{29}\right)$ He remained as editor of this journal for all 25 volumes, until 1920.

$\left.{ }^{(30}\right)$ Poggendorff's Annalen der Physic, Annales des mines, The American Journal of Science and Art, Gelehrte Anzeiger, Erddmann's Journal für praktische Chemie, Zeitschrift der deutschen geologiche Gesellschaft, Neues Jahrbuch für Mineralogie Geologie Geognosie und Petrefakunde.

$\left.{ }^{(31}\right)$ James Dwight Dana (1813-1895), the famous American geologist and zoologist, was Professor of Geology at Yale and foreign correspondent to the Lincei. During his visit to Italy in 1833-34, he observed the volcanic activity of Vesuvius and, in the American Journal of Science, published: On the condition of Vesuvius in July 1834. In 1836 he became Silliman's assistant at Yale. From 1838 to 1842 he participated as the resident geologist in the largest American oceanic expedition of the nineteenth century, under Wilkes. Author of the very successful A System of Mineralogy, New Haven, Durre \& Peck and Harrick \& Noyes, 1837, and the Manual of Geology (Philadelphia, Bliss, 1869), he was also involved in important geological and palaeontological studies of, among other things, the Appalachian mountains. He supported the theory of geosyncline and the role of orogenesis. The letters written to Scacchi cover the period 1853 to 1890 (and do not date from 1845, as is erroneously stated in the Gravina collection and in Raguso, F., D'Agostino, M. (1993). Dana most probably met Scacchi during his visit to Naples in 1833-34.

${ }^{32}$ ) He wrote to Scacchi: «Further to the communication I received from Prof. Cannizzaro on your behalf, I am sending you without delay the substances you requested, and at the same time I would like to express my gratitude to you for the assistance you have been so kind as to offer me in my research.» Translation mine. Palermo, October 9, 1869, BPSG, B 4, F 12, N 57. Wilhelm Körner (1839-1925), a German organic chemist, worked with Kekulé at Gand and in Bonn; for health reasons, he moved to Italy, Palermo, where he worked with Cannizzaro. Körner took part in the project which led to the development of the theory of aromatic compounds.

${ }^{(33}$ ) Luigi Palmieri (1807-1896), physicist, volcanologist and philosopher. He directed the Osservatorio Vesuviano from 1850 and the Specola Universitaria from 1860; he was a correspondent for the Lincei (1871). In 1860 he won the Chair of Earth Physics. His work in physics dealt with questions concerning induced electrical currents (in particular telluric currents), atmospheric electricity and volcanology. His physical-chemical and spectroscopic work on volcanoes and lava was of particular importance; he also developed the method for determining the liquidity of lava. In 1856 he invented a seismograph which was set up on Vesuvius to record earthquakes preceding eruptions. He was a great friend of Scacchi, with whom on occasions he worked. Together they wrote the paper on Vulture (1852). He is also the author of: Sull'origine dell'elettricità atmosferica, Naples, Fibreno, 1862. ${ }^{\left({ }^{34}\right)}$ Guglielmo Guiscardi (1821-1885), was Scacchi's student and assistant. He accompanied both Lyell and Mallet on their Neapolitan excursions and his help was greatly appreciated by both scientists. He was the curator of the Geological Museum in Naples from 1866 (the year it was founded) to 1885. The Geological Museum at Trinity College, Dublin, houses, amongst other things, the entire remains of the Guiscardi-Haughton collection (see WYSE JACKSON, P.N. (1998).

$\left({ }^{35}\right)$ Charles Lyell (1797-1875), the Scottish geologist, was a proponent of the theory of uniformity and the author of Principles of Geology, (1830-33) which had a significant impact on the history of geology, influencing the work of Charles Darwin. He was the first to suggest the subdivision of the Cenozoic era into the Eocene, Miocene, Pliocene and Pleistocene. He studied the formation and structure of volcanoes and recognised the correlation between volcanology, seismic activity and tectonics. He was Professor of Geology at King's College, London from 1831 and was elected President of the Royal Geological Society in 1835.

$\left.{ }^{(36}\right)$ With the publication of Principles of Geology, London, Murray, 1830-1833.

$\left({ }^{37}\right)$ In the sense that, as Rudwick points out, when Lyell left, the general outline of his book was already clear and he was aware of having formulated a revolutionary theory; the aim of his visit was to gain first hand experience of phenomena that might be used as persuasive examples for his argument. See RUDWICK, M.J.S.(1969), cf. p. 289.

$\left({ }^{38}\right)$ In 1825 the first treatise on volcanoes was published (Considerations on volcanoes: the probable causes of their phenomena, the laws which determine their march, the disposition of their products and their connexion with the present state and past history of the globe: leading to the establishment of a new theory of the earth, London, Phillips, Yard, 1825) had been published by GEORGE PoUlET SCROPE (1797-1876) who, taking into con- 
sideration the work of Italian scholars, proved the doubtful nature of the theory of crater upheaval in the formation of volcanoes.

$\left({ }^{39}\right)$ According to this theory, the birth of a volcano, like that of a mountain, is due to endogenic upheaval and not to rock accumulation after an eruption. Leopold von Buch (1774-1853) «links volcanic activity to sudden, violent upward movements of the ground. Volcanoes are formed by the accumulation of scoriae and lava: the pressure of incandescent underground masses pushes the ground upwards, thus causing the previously horizontal strata to form reliefs; the peak then explodes, leading to the formation of an eruptive cone inside the crater. Vesuvius,» von Buch wrote, «emerged from the mound of earth that sprang up in 79 BC» LA VERGATA, A. (1989), p. 567.

$\left({ }^{40}\right)$ LYELL, C. (1849).

$\left({ }^{41}\right)$ SCACCHI, A. (1849).

$\left({ }^{42}\right)$ LYELL, C. (1849), cit., p. 226.

$\left({ }^{43}\right)$ On the subject of the formation of Monte Nuovo (in 1538), the Temple of Serapis (where he cites Scacchi's opinion as being exact), and the eruption of Vesuvius (1850).

${ }^{(44}$ ) Letter from Scacchi to De Medici Spada, 16 October 1845, Biblioteca Comunale Saffi, Forlì, Collezione Piancastelli. Lavinio de Medici Spada (1801-1863), man of letters, politician and mineralogist. He was interested in botany, but is best known for his mineral collection, which was bought by the Vatican in 1851 for the University of Rome and which today still forms the nucleus of the mineralogical museum.

$\left({ }^{45}\right)$ Giacinto Provana di Collegno (1794-1856), a nobleman from Turin, an officer in the armed forces and a member of the Carboneria, he had a direct role in the Revolution of March 1821. In exile in Genoa and Marseilles he devoted himself first to botany and then to the study of geology.

$\left({ }^{46}\right)$ Letter from Lyell to Scacchi, London, 27 May 1852, BPSG, B 4, F 11, N 30.

$\left({ }^{47}\right)$ See Rudwick, M. (1996), p. 282.

$\left({ }^{48}\right)$ RUDWICK, M. (1969), cit., in particular, p. 291.

$\left({ }^{49}\right)$ LYELL, C. (1875), vol. II, cap. XXX.

$\left({ }^{50}\right)$ Quart. Journ. Geol. Soc., vol. III, p. 237.

$\left({ }^{51}\right)$ See letter from Lyell to Scacchi, 1852.

$\left({ }^{52}\right)$ LYELL, K.M.(ed.) (1881), Berlin, March 24, 1855, pp. 203-204.

$\left({ }^{53}\right)$ LEONARD HORNER (1785-1864), geologist, founder of the Edinburgh Review (1802), president of the Royal Geological Society (1845-47 and 1860-62). One of Darwin's correspondents.

$\left({ }^{54}\right)$ SCACCHI, A. (1850).

$\left({ }^{55}\right)$ See note 20 .

$\left({ }^{56}\right)$ The geologist and mineralogist Ours-Pierre-Armand-Petit Dufrénoy (1792-1857) began work in 1823 on a geological map survey of France with E. Beaumont, which was published in 1836. He published work on the geology of the Massif Central, on southern France, and on the formation of Monte Somma and Vesuvius.

$\left({ }^{57}\right)$ LYELL, K. M. (ed.) (1881), cit., p. 203 letter to Horner.

$\left({ }^{58}\right) I v i$, letter to George Hartung, Naples, October 16, 1857, pp. 273- 275.

$\left({ }^{59}\right) I v i$, p. 274.

$\left({ }^{60}\right)$ LYELL C. (1875), cit., vol. I, p. 635.

( ${ }^{61}$ ) Robert Mallet (1810-1881), Irish engineer and seismologist. He was involved in several public works projects and in the field of industrial construction. His work as a civil engineer led him to study questions regarding the earth's surface and related dynamics; his work on the statistics and dynamics of earthquakes and on seismic wave velocity assured him of recognition as one of the founders of seismology, a term he himself coined.

$\left({ }^{62}\right)$ December 16, 1857.

$\left({ }^{63}\right)$ Letter from Lyell to Scacchi, London, January 25, 1858, BPSG, B 4, F11. N 30.

The observation work carried out in the Naples area led to the publication of Great Neapolitan Earthquake of 1857, a work which was to become a key text in the history of seismology. In the introduction, Mallet acknowledges the enormous help he received from his Italian colleagues - Scacchi, Palmieri and Guiscardi.

$\left({ }^{64}\right)$ The tribute was from JoHnSTON-LAVIS, H.S. (the representative of the London Geological Society and the British Mineralogical Society) (1891). On his eighty-first birthday, February 8, 1891, Scacchi received a medal engraved with his own portrait, as well as awards from other research establishments, at home and abroad, for his scholarly contribution to science. 


\section{REFERENCES}

JoHNSTON-LAVIS, H.S. (1891): Cinquantesimo anniversario dell'insegnamento di Arcangelo Scacchi, (Tipografia della Reale Università, Napoli).

La Vergata, A. (1989): Geologia e paleontologia fra la metà del Settecento e la metà dell'Ottocento, in Storia della scienza moderna e contemporanea, Vol. II, edited by P. Rossi, (Utet, Torino).

Lyell, C. (1830-1833): Principles of Geology, (Murray, London).

Lyell, C. (1849): On Craters of Denudation, with Observations on the Structure and Growth of Volcanic Cones, The Quarterly Journal of the Geological Society of London, (Proceedings of the Geological Society, December 19).

LYELL, C. (1875): Principles of geology, (Murray, London).

LYELL, K.M. (Ed.) (1881): Life, letters and journal of sir Charles Lyell, (Murray, London).

MaLLET, R. (1862): Great Neapolitan earthquake of 1857. The first principles of observational seismology, Vol. II, (Chapman and Hall, London) (rist. anast., ING and SGA, 1987).

Millosevich, F. (1936): Scacchi Arcangelo, in Enciclopedia Italiana, (Treccani, Roma), vol. XXX.

MotTana, A. (1993): Ricordo di Arcangelo Scacchi a cent'anni dalla morte, in Rend. Accad. Ital. Sc., detta dei XL, Mem. Sc. Fis. Nat., s. 5, vol. 17, pp. 45-74.

MotTAna, A. (2001): Arcangelo Scacchi: massimo scopritore di minerali al Vesuvio, in Atti del Bicentenario Real Museo Mineralogico, edited by M.R. GHIARA and C. PetTi, (Mediasitalia, Napoli).
Palmieri, L. and A. SCACCHI (1852): Della regione vulcanica del Monte Vulture e del tremuoto ivi avvenuto nel dì 14 Agosto 1851, (Relazione fatta per incarico della Reale accademia delle Scienze, Napoli, Nobile).

Raguso, F., M. D’Agostino (1993): Arcangelo Scacchi. Pietra miliare. Cristallografia, mineralogia, vulcanologia, (Teleservice, Gravina).

RUDwICK, M.J.S. (1969): Lyell on Etna, and the antiquity of the Earth, in Toward a History of Geology, edited by C. J. SCHNEER, (The M.I.T. Press, Cambridge).

RuDWICK, M. (1996): Mineral, strata and fossil, in Cultures of Natural History, edited by N. JARDINE, J.A. SECORD, E.C. SPARY (Cambridge University Press, Cambridge).

SCACCHI, A. (1849): Memorie geologiche della Campania. Memoria I, Rend. Acc. Sc. Fis. e Mat., 8 [43], pp. 4165, Memoria II, 8 [44-45], pp.115-140, Memoria III, 8 [48], pp. 317-335, 9 [50], pp. 84-114, Napoli.

SCACCHI, A. Relazione dell'incendio accaduto nel Vesuvio nel mese di febbraio del 1850, seguita dai giornalieri cambiamenti osservati in questo vulcano dal $1840 \mathrm{sin}$ ora, in Rend. R. Acc. delle Scienze Fis. e nat., 9, 49, Naples, 1850 , pp. 13-48; trans. into French by Damour and published in "Annales des Mines», De la derniére eruption du Vésuve arrivée en fevrier $1850 \ldots, 4^{\circ}$ serie, t. XVII, Paris, 1850 , pp. 323-380.

SCACCHI A. (1851): Della humite e del peridoto del Vesuvio, in Atti della R. Acc. delle scienze di Napoli, 6, pp. 241-273.

WYSE JACKSON, P.N. (1998): Hibernian research on Italian volcanic rocks. The Mallet and Guiscardi/Haughton Collections in Trinity College, Dublin, in Volcanoes and history, edited by M. MoRELLO, (INHIGEO, Genova, Brigati). 